\title{
GC-MS Analysis of Frankincense Extracts which Inhibit the Growth of Bacterial Triggers of Selected Autoimmune Diseases
}

\author{
Isaac Biggs ${ }^{1}$, Joseph Sirdaarta ${ }^{1,2}$, Alan White ${ }^{1}$, Ian Edwin Cock ${ }^{1,2}$ \\ 'School of Natural Sciences, Nathan Campus, Griffith University, 170 Kessels Road, Nathan, Queensland 4111, AUSTRALIA. \\ 2Environmental Futures Research Institute, Nathan Campus, Griffith University, 170 Kessels Road, Nathan, Queensland 4111, AUSTRALIA.
}

\begin{abstract}
Introduction: Frankincense has been used traditionally for the inhibition of microbial growth and for the treatment of rheumatic diseases. Despite this, frankincense extracts are yet to be tested for the ability to inhibit the growth of the bacterial triggers of autoimmune inflammatory diseases. Methods: Solvent extracts prepared from commercially obtained frankincense were analysed for the ability to inhibit the growth of bacterial species associated with initiating rheumatoid arthritis ( $P$. mirabilis), ankylosing spondylitis ( $K$. pneumoniae) and multiple sclerosis (A. baylyi, P. aeruginosa) by disc diffusion assay, and quantified by MIC determination. Toxicity was determined by Artemia franciscana bioassay. The most potent inhibitory extracts were investigated using non-targeted GC-MS head space analysis (with screening against a compound database) for the identification and characterisation of individual components in the crude plant extracts. Results: Methanolic and aqueous frankincense extracts inhibited the growth of all bacterial species. The growth inhibition of these extracts was particularly notable against $P$. mirabilis and $K$. pneumoniae, with MIC values generally $\leq 1000 \mu \mathrm{g} / \mathrm{mL}$ for both reference and clinical bacterial strains. Indeed, the MIC values of the methanolic extract against $P$. mirabilis, and for the aqueous extract against $K$. pneumonia, were as low as 59.6 and $75.2 \mathrm{\mu g} / \mathrm{mL}$ respectively. The methanolic and aqueous extracts also inhibited the growth of $A$. baylyi and $P$. aeruginosa. However, with the exception of the growth inhibition of $A$. baylyi by the aqueous extract $(\mathrm{MIC}=4313 \mu \mathrm{g} / \mathrm{mL}$ : moderate inhibitory activity), the MICs against these bacteria was indica-
\end{abstract}

tive of only low inhibitory activity. The ethyl acetate, chloroform and hexane extracts also inhibited the growth of all bacterial species, albeit with low efficacy (MIC values generally $>5000 \mu \mathrm{g} / \mathrm{mL}$ against all bacterial species). All frankincense extracts were non-toxic in the Artemia franciscana bioassay, with $L_{50}$ values substantially above $1000 \mu \mathrm{g} / \mathrm{mL}$. Non-biased GC-MS headspace analysis of the methanolic and aqueous extracts putatively identified a high diversity of monoterpenoids and sesquiteriterpenoids. Conclusion: The lack of toxicity and the inhibitory activity of the methanolic and aqueous frankincense extracts against microbial triggers of rheumatoid arthritis and ankylosing spondylitis indicates their potential in the treatment and prevention of these diseases.

Key words: Boswellia, Terpenoid, Monoterpene, Sesquitertene, Rheumatoid Arthritis, Ankylosing spondylitis, Multiple sclerosis.

\section{Correspondence:}

Dr. Ian Edwin Cock, School of Natural Sciences and Environmental Futures Research Institute Nathan Campus, Griffith University, 170 Kessels Rd, Nathan, Queensland 4111, AUSTRALIA.

Phone no: +61 7 37357637; Fax no: +61 737355282

E-mail: I.Cock@griffith.edu.au

DOI : $10.5530 /$ pc.2016.1.3

\section{INTRODUCTION}

Frankincense resin, obtained from trees of the genus Boswellia (family Burseraceae), has been traded on the Arabian Peninsula and in Northern Africa since ancient times. It has long been valued for its health promoting properties and therapeutic effects. Its use is depicted in an Egyptian wall mural dating to approximately $1458 \mathrm{BC}$, as well as in the religious texts of several major religions. ${ }^{1}$ Three main Boswellia spp. (B. carteri Birdw.,B. frereana Birdw. and B. serrata Roxb.) account for nearly all of the global production of frankincense. ${ }^{2}$. The resin is harvested by cutting incisions through the papery bark of mature trees and allowing the resinous exudates to seep out and harden into the orange-brown resin commonly known as frankincense. ${ }^{3}$

There are frequent references to the use of frankincense in religious texts, accounting for its extensive burning as incense in Christian, Jewish and several Orthodox religious ceremonies. ${ }^{4}$ Nowadays, the primary use of frankincense is in perfumery and for aromatherapy. However, a wide variety of therapeutic uses have also been attributed to frankincense, including the treatment of skin diseases, urinary tract infections, respiratory infections, to aid in wound healing, as well as for digestive and gastrointestinal disorders. ${ }^{5}$ Many of these conditions are related to bacterial infections and several studies have reported the growth inhibitory properties of frankincense against panels of pathogens. One study screened $B$. serrata extracts for the ability to inhibit the growth of an extended panel of microbial pathogens associated with skin infections. ${ }^{6}$ That study tested 18 aerobic and 9 anaerobic bacterial strains (including antibiotic resistant strains), as well as 3 fungal strains. The B. serrata extracts inhibited the growth of 10 of the 18 aerobic bacteria, and 5 of the 9 anaerobic bacterial strains tested. Furthermore, the MIC values reported in that study were as low as $1 \mu \mathrm{g} / \mathrm{mL}$ against some Streptococcus spp., Cornybacterium spp., Clostridium spp., Propionobacterium spp. and Porphyromonas spp. In contrast, none of the fungal species tested was affected by the $B$. serrata extracts. In another study, essential oils produced by steam distillation of frankincense resins were reported to inhibit the growth of reference bacterial strains of Bacillus cereus, Escherichia coli and Staphylococcus aureus, as well as the fungal pathogen Candida albicans, with MIC values indicative of moderate growth inhibitory activity. ${ }^{7}$ A more recent study reported growth inhibitory activity of a frankincense extract against a broader panel of bacterial species, ${ }^{8}$ although the value of that study was limited as the extract was only tested at very high concentrations $(25-100 \mathrm{mg} / \mathrm{mL})$, making it difficult to compare this activity to that of other antibacterial chemotherapies.

Frankincense has also been used traditionally in the treatment of several inflammatory diseases including rheumatoid arthritis ${ }^{9}$ and Crohn's disease. ${ }^{10}$ The anti-inflammatory activities and mechanisms of frankincense have been relatively well studied and apleuripotent mechanism has been proposed. One study reported that $B$. carterii extract regulates the production of cytokines in mouse cell cultures. ${ }^{11}$ Specifically, the extract inhibited the production of IFN- $\gamma$ and IL-2. In contrast, the same study reported that production of IL-4 and IL-10 was increased substan- 
tially following exposure to the $B$. carterii extract (more than double at some extract concentrations). Other studies have also demonstrated that $B$. serrata extracts strongly inhibit cellular and humoral immune responses in mice. ${ }^{12}$ Oral administration of the B. serrata extract strongly inhibited antibody production and cellular responses, as well as inhibiting polymorphonuclear leucocyte infiltration.

Despite the traditional uses of frankincense in the treatment of inflammatory disease, as well as the well-established growth inhibitory activity of frankincense against other bacterial pathogens, frankincense has not been studied for the ability to block the microbial triggers of autoimmune inflammatory diseases. This may result from a poor understanding of many of these disorders. However, recent serotyping studies have identified bacterial triggers of some of these conditions and the bacterial antigens responsible for the induction of an immune response (Table 1) allowing for studies to examine the ability to inhibit the trigger mechanisms of these diseases. The major microbial trigger of rheumatoid arthritis has been identified as Proteus mirabilis, ${ }^{13-5}$ a normal part of the human gastrointestinal flora. Similarly, Klebsiella pneumoniae has been shown to initiate ankylosing spondylitis ${ }^{16-8}$ and Acinetobacter baylyi and Pseudomonas aeruginosa have been linked with the onset of multiple sclerosis. ${ }^{19-21}$ The development of antibiotic agents targeted at the specific bacterial triggers of autoimmune inflammatory disorders would enable afflicted individuals to target these microbes and thus prevent the onset of the disease and reduce the severity of the symptoms once the disease has progressed. The current study examined the ability for frankincense extracts to block the initiating events of several autoimmune inflammatory diseases by blocking their microbial triggers.

\section{MATERIALS AND METHODS}

\section{Frankincense source and extraction}

Frankincense was originally sourced from verified Boswellia carteriBirdw. trees in Oman by Noodles Emporium, Australia and supplied as a dry resin. Voucher samples have been stored in the School of Natural Sciences, Griffith University. Prior to use, the resin was freshly ground to a coarse powder and $1 \mathrm{~g}$ quantities were weighed into separate tubes. Individual $50 \mathrm{~mL}$ volumes of methanol, water, ethyl acetate, chloroform or hexane were added to the ground resin and extracted by maceration for 24 hours at $4^{\circ} \mathrm{C}$ with gentle shaking. The extracts were subsequently filtered through filter paper (Whatman No. 54) under vacuum, followed by drying by rotary evaporation in an Eppendorf concentrator 5301. The resultant dry extract was weighed and redissolved in $10 \mathrm{~mL}$ deionised water (containing 0.5\% DMSO). All solvents were obtained from Ajax Australia and were AR grade.

\section{Qualitative phytochemical studies}

Phytochemical analysis of the fruit extracts for the presence of saponins, phenolic compounds, flavonoids, polysteroids, triterpenoids, cardiac glycosides, anthraquinones, tannins and alkaloids was conducted by previously described assays. ${ }^{22-4}$

\section{Antibacterial screening}

\section{Test microorganisms}

All media was supplied by Oxoid Ltd. Australia. Reference strains of Klebsiella pneumoniae (ATCC31488), Proteus mirabilis (ATCC21721), Acinitobacterbaylyi (ATCC33304) and Pseudomonas aeruginosa (ATCC39324) were purchased from American Tissue Culture Collection, USA. All other clinical microbial strains were obtained from the School of Natural Sciences teaching laboratory, Griffith University. All stock cultures were subcultured and maintained in nutrient broth at $4^{\circ} \mathrm{C}$.

\section{Evaluation of antimicrobial activity}

Antimicrobial activity of all plant extracts was determined using a modified disc diffusion assay. ${ }^{25-7}$ Briefly, $100 \mu \mathrm{L}$ of the test bacteria were grown in $10 \mathrm{~mL}$ of fresh nutrient broth media until they reached a count of approximately $10^{8}$ cells $/ \mathrm{mL}$. An amount of $100 \mu \mathrm{L}$ of bacterial suspension was spread onto nutrient agar plates. The extracts were tested for antibacterial activity using $5 \mathrm{~mm}$ sterilised filter paper discs. Discs were impregnated with $10 \mu \mathrm{L}$ of the test sample, allowed to dry and placed onto inoculated plates. The plates were allowed to stand at $4^{\circ} \mathrm{C}$ for 2 hours before incubation with the test microbial agents. Inoculated plates were incubated at $30^{\circ} \mathrm{C}$ for 24 hours, then the diameters of the inhibition zones were measured to the closest whole millimetre. Each antimicrobial assay was performed in at least triplicate. Mean values $( \pm$ SEM) are reported in this study. Standard discs of ampicillin $(10 \mu \mathrm{g})$ were obtained from Oxoid Ltd. Australia and served as positive controls for antibacterial activity. Filter discs impregnated with $10 \mu \mathrm{L}$ of distilled water were used as a negative control.

\section{Minimum inhibitory concentration (MIC) determination}

The minimum inhibitory concentration (MIC) of the extracts were determined as previously described. ${ }^{28-9}$ Briefly, the plant extracts were diluted in deionised water and tested across a range of concentrations. Discs were impregnated with $10 \mu \mathrm{L}$ of the test dilutions, allowed to dry and placed onto inoculated plates. The assay was performed as outlined above and graphs of the zone of inhibition versus concentration were plotted for each extract. Linear regression was used to calculate the MIC values.

\section{Toxicity screening}

\section{Reference toxin for toxicity screening}

Potassium dichromate $\left(\mathrm{K}_{2} \mathrm{Cr}_{2} \mathrm{O}_{7}\right)$ (AR grade, Chem-Supply, Australia) was prepared as a $1.6 \mathrm{mg} / \mathrm{mL}$ solution in distilled water and was serially diluted in artificial seawater for use in the Artemia franciscana nauplii bioassay.

\section{Artemia franciscana nauplii toxicity screening}

Toxicity was tested using a modified Artemia franciscana nauplii lethality assay. ${ }^{30-2}$ Briefly, $400 \mu \mathrm{L}$ of seawater containing approximately 48 (mean $47.8, \mathrm{n}=120, \mathrm{SD} 10.7)$ A. franciscana nauplii were added to wells of a 48 well plate and immediately used for bioassay. A volume of $400 \mu \mathrm{L}$ of diluted plant extracts or the reference toxin were transferred to the wells and incubated at $25 \pm 1^{\circ} \mathrm{C}$ under artificial light (1000 Lux). A negative control ( $400 \mu \mathrm{L}$ seawater) was run in triplicate for each plate. All treatments were performed in at least triplicate. The wells were checked at regular intervals and the number of dead counted. The nauplii were considered dead if no movement of the appendages was observed within 10 seconds. After $24 \mathrm{~h}$, all nauplii were sacrificed and counted to determine the total \% mortality per well. The LC50 with 95\% confidence limits for each treatment was calculated using probit analysis.

\section{Non-targeted GC-MS head space analysis}

Separation and quantification were performed using a Shimadzu GC-2010 plus (USA) linked to a Shimadzu MS TQ8040 (USA) mass selective detector system as previously described. ${ }^{21}$ Briefly, the system was equipped with a Shimadzu auto-sampler AOC-5000 plus (USA) fitted with a solid phase micro-extraction fibre (SPME) handling system utilising a Supelco (USA) divinyl benzene/carbowax/polydimethylsiloxane (DVB/CAR/PDMS). Chromatographic separation was accomplished using a $5 \%$ phenyl, $95 \%$ dimethylpolysiloxane $(30 \mathrm{~m} \times 0.25 \mathrm{~mm}$ id $\times 0.25$ um) capillary column (Restek USA). Helium (99.999\%) was employed as a carrier gas at a flow rate of $0.79 \mathrm{~mL} / \mathrm{min}$. The injector temperature was set at $230^{\circ} \mathrm{C}$. Sampling utilised a SPME cycle which consisted of an 
Table 1: The bacterial triggers of the selected autoimmune inflammatory diseases as well as the bacterial antigen and host susceptibility antigen sequences

\begin{tabular}{|c|c|c|c|c|c|c|}
\hline Disease & Bacterial Trigger & Bacterial Antigen & $\begin{array}{l}\text { Bacterial } \\
\text { Sequence }\end{array}$ & Host Antigen & Host Sequence & References \\
\hline \multirow[t]{2}{*}{ Rheumatoid arthritis } & $\begin{array}{l}\text { Proteus mirabilis and } \\
\text { possibly also other Proteus }\end{array}$ & haemolysin & ESRRAL & $\begin{array}{c}\text { MHC class } 2 \text { allele } \\
\text { HLA-DR4 }\end{array}$ & EQ/KRRAA & $13-15$ \\
\hline & spp. & urease & IRRET & type XI collagen & LRREI & $13-15$ \\
\hline \multirow{3}{*}{ Ankylosing spondylitis } & & $\begin{array}{l}\text { nitrogenase reductase } \\
\text { enzyme }\end{array}$ & QTDRED & $\begin{array}{c}\text { MHC class } 1 \text { allele } \\
\text { HLA-B27 }\end{array}$ & QTDRED & $16-18$ \\
\hline & Klebsiella pneumoniae & pullulanase & DRDE & $\begin{array}{c}\text { MHC class } 1 \text { allele } \\
\text { HLA-B27 }\end{array}$ & DRED & $16-18$ \\
\hline & & pullulanase & $\mathrm{GxP}$ & $\begin{array}{l}\text { types I, III and IV } \\
\text { collagen }\end{array}$ & $\mathrm{GxP}$ & $16-18$ \\
\hline \multirow{4}{*}{ Multiple sclerosis } & Pseudomonas aeriginosa & $\Upsilon$-CMLD & TRHAYG & $\begin{array}{l}\text { Myelin-neuronal } \\
\text { antigen MBP }\end{array}$ & SRFSYG & $19-21$ \\
\hline & & 4-CMLD & SRFAYG & $\begin{array}{l}\text { Myelin-neuronal } \\
\text { antigen MBP }\end{array}$ & SRFSYG & $19-21$ \\
\hline & Acinetobacter spp. & 3-OACT-A & LTRAGK & $\begin{array}{l}\text { Myelin-neuronal } \\
\text { antigen MOG }\end{array}$ & LYRDGK & $19-21$ \\
\hline & & $\begin{array}{l}\text { Acinetobacter } \\
\text { regulatory protein }\end{array}$ & ${ }^{\star} \mathrm{KKVEEI}$ & $\begin{array}{l}\text { Neurofilament-M } \\
\text { protein }\end{array}$ & ${ }^{\star}$ KKVEEI & $19-21$ \\
\hline
\end{tabular}

MOG = myelin oligodendrocyte glycoprotein; MBP = myelin basic protein; 4-CMLD = 4-carboxy-muconolactone decarboxylase; 3-OACT-A = 3-oxoadipate CoAtransferase; $\Upsilon$-CMLD $=\Upsilon$-carboxy-muconolactone decarboxylase. ${ }^{*}$ indicates the sequence likely to be responsible for cross-reactivity, although this is yet to be confirmed.

agitation phase at $500 \mathrm{rpm}$ for a period of $5 \mathrm{sec}$. The fibre was exposed to the sample for $10 \mathrm{~min}$ to allow for absorption and then desorbed in the injection port for $1 \mathrm{~min}$ at $250^{\circ} \mathrm{C}$. The initial column temperature was held at $30^{\circ} \mathrm{C}$ for $2 \mathrm{~min}$, increased to $140^{\circ} \mathrm{C}$ for $5 \mathrm{~min}$, then increased to $270^{\circ} \mathrm{C}$ over a period of 3 mins and held at that temperature for the duration of the analysis. The GC-MS interface was maintained at $200^{\circ} \mathrm{C}$ with no signal acquired for a min after injection in split-less mode. The mass spectrometer was operated in the electron ionisation mode at $70 \mathrm{eV}$. The analytes were then recorded in total ion count (TIC) mode. The TIC was acquired after a min and for duration of 45 mins utilising a mass range of $45-450 \mathrm{~m} / \mathrm{z}$.

\section{Statistical analysis}

Data are expressed as the mean \pm SEM of at least three independent experiments.

\section{RESULTS}

\section{Liquid extraction yields and qualitative phytochemical screening}

Extraction of $1 \mathrm{~g}$ of frankincense with the solvents yielded dried extracts ranging from $124 \mathrm{mg}$ (aqueous extract) to $869 \mathrm{mg}$ (methanolic and chloroform extract) (Table 2). With the exception of the aqueous extract, all solvents extracted similar quantities of frankincense material $(800-870 \mu \mathrm{g} / \mathrm{mL})$. This is indicative of the high amounts of mid-low polarity compounds in the frankincense resin. The dried extracts were resuspended in $10 \mathrm{~mL}$ of deionised water (containing 1\% DMSO), resulting in the extract concentrations shown in Table 2.

Qualitative phytochemical studies showed that all solvents extracted similar classes of phytochemicals. All had low to moderate levels of phenolics. Whilst all extracts also contained saponins, the levels were high in the methanolic, aqueous and hexane extracts, but low in the aqueous and chloroform extracts. The levels of flavonoids was another difference between the extracts, only being detected in the methanolic and aqueous extracts in moderate to high levels, and in low levels in the hexane extract. All other extracts lacked detectable levels of flavonoids. All extracts were generally devoid of all other classes of phytochemicals.

\section{Antimicrobial activity}

To determine the growth inhibitory activity of the frankincense extracts against the bacterial triggers of the autoimmune inflammatory diseases, aliquots $(10 \mu \mathrm{L})$ of each extract were tested in the disc diffusion assay. Reference and clinical strains of $P$. mirabilis were inhibited by all frankincense extracts (Figure 1). The methanolic extract was the most potent P. mirabilis growth inhibitor (as assessed by the sizes of the zones of inhibition), with $9.3 \pm 0.3$ and $8.9 \pm 0.6 \mathrm{~mm}$ for the reference and clinical strains respectively. The ethyl acetate extract was also a moderate inhibitor of $P$. mirabilis growth, with zones of inhibition of approximately $8 \mathrm{~mm}$ for both strains. Whilst the other extracts also inhibited $P$. mirabilis growth, their inhibition was substantially weaker, with inhibition zones generally $\leq 7.5 \mathrm{~mm}$ in diameter (compared to $>10.5 \mathrm{~mm}$ for the ampicillin control). The growth of K. pneumoniae (Figure 2) was generally more susceptible to inhibition by the frankincense extracts than was P. mirabilis (as judged by the zones of inhibition). Both polar and low polarity extracts were generally good K. pneumoniae growth inhibitors, however the higher polarity aqueous and methanolic extracts were generally more potent. Indeed, both the methanolic and aqueous extracts showed zones of inhibition of $>8 \mathrm{~mm}$ against both the reference and clinical strains of the bacterium. This compares well with the growth inhibition of the positive control (ampicillin, $10 \mu \mathrm{g}$ ), which had inhibition zones of 7-7.3 mm against both strains. The lower polarity ethyl acetate, chloroform and hexane extracts also inhibited K. pneumoniae growth, albeit with smaller zones of inhibition $(6.9-7.5 \mathrm{~mm})$ than the higher polarity extracts.

Both reference and clinical strains of $A$. baylyi were also inhibited by all of the frankincense extracts (Figure 3). Both strains appeared to be 
Table 2: The mass of dried extracted material, the concentration after resuspension in deionised water, qualitative phytochemical screenings and antioxidant capacities of the frankincense extracts

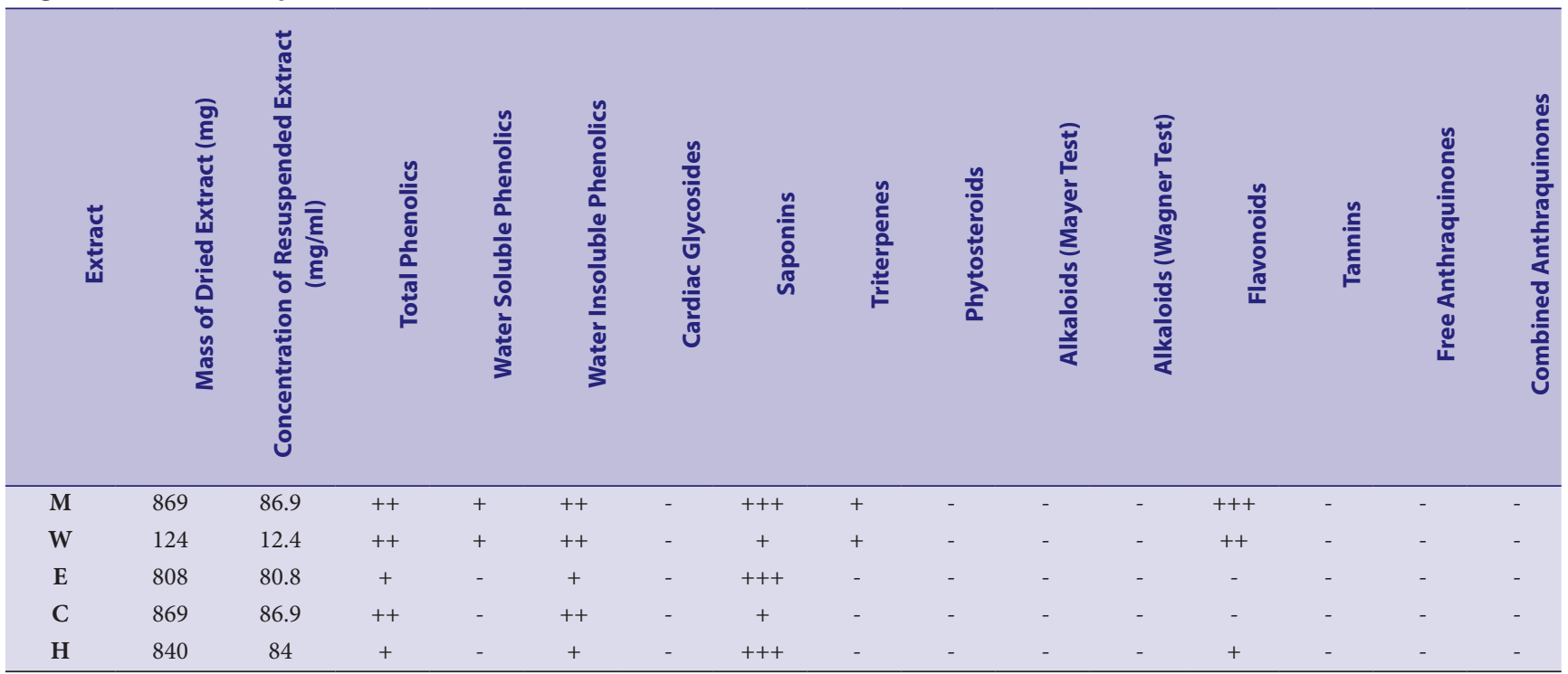

+++ indicates a large response; ++ indicates a moderate response; + indicates a minor response; - indicates no response in the assay. $\mathrm{M}=$ methanolic frankincense extract; $\mathrm{W}=$ aqueous frankincense extract; $\mathrm{E}=$ ethyl acetate frankincense extract; $\mathrm{C}=$ chloroform frankincense extract; $\mathrm{H}=$ hexane frankincense extract.

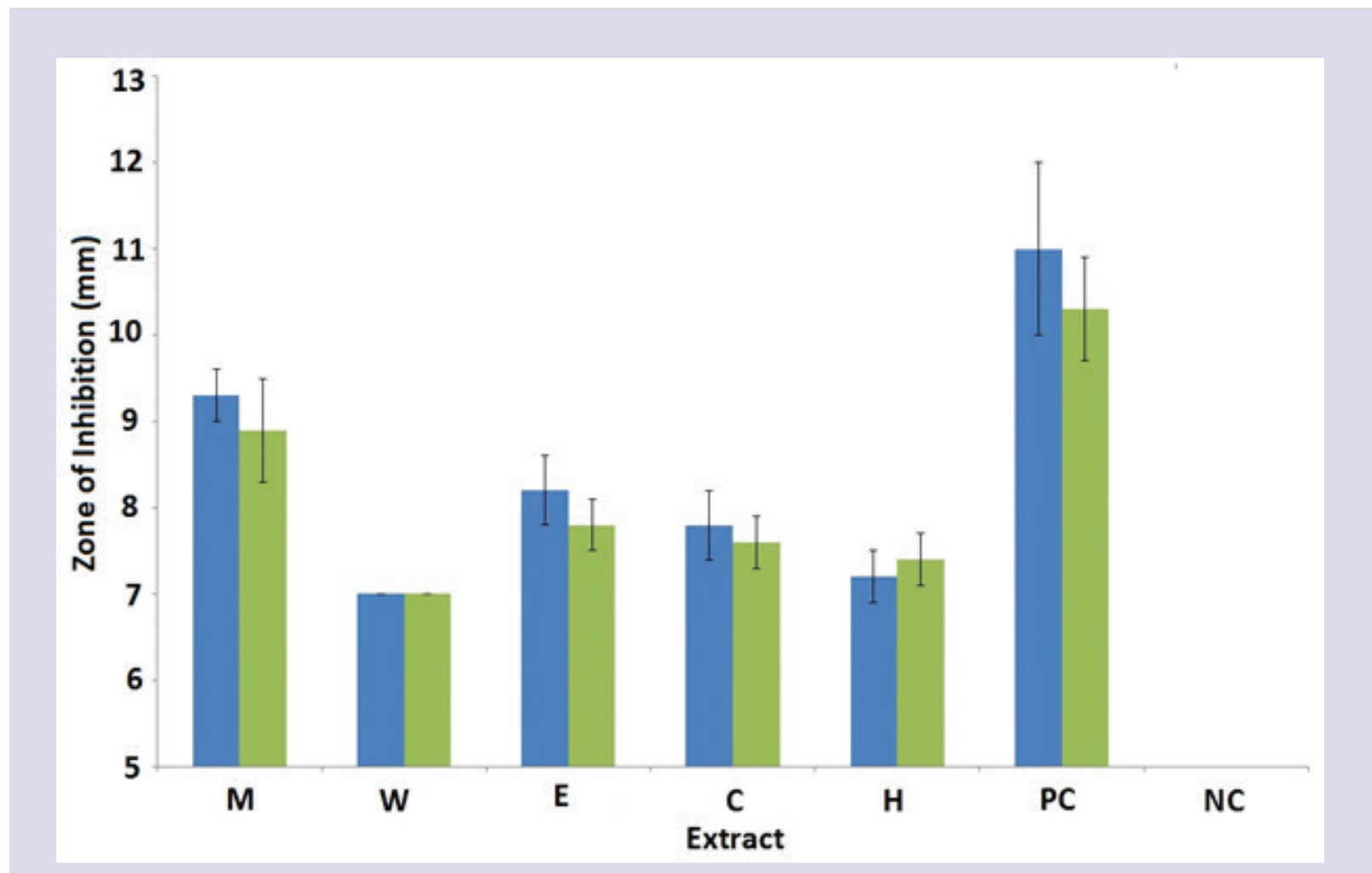

Figure 1: Antibacterial activity of the frankincense extracts against $P$. mirabilis measured as zones of inhibition ( $\mathrm{mm}$ ). The blue bars represent the inhibitory activity against the reference strain (ATCC:21721) and the green bars represent the zones of inhibition against the clinical strain. $\mathrm{M}=$ methanolic extract; $\mathrm{W}=$ water extract; $\mathrm{E}=$ ethyl acetate extract; $\mathrm{C}=$ chloroform extract; $\mathrm{H}=$ hexane extract; $\mathrm{NC}=0.5 \% \mathrm{DMSO}$ $\mathrm{PC}=$ ampicillin $(10 \mu \mathrm{g})$ control. Results are expressed as mean zones of inhibition $\pm \mathrm{SEM}$. 


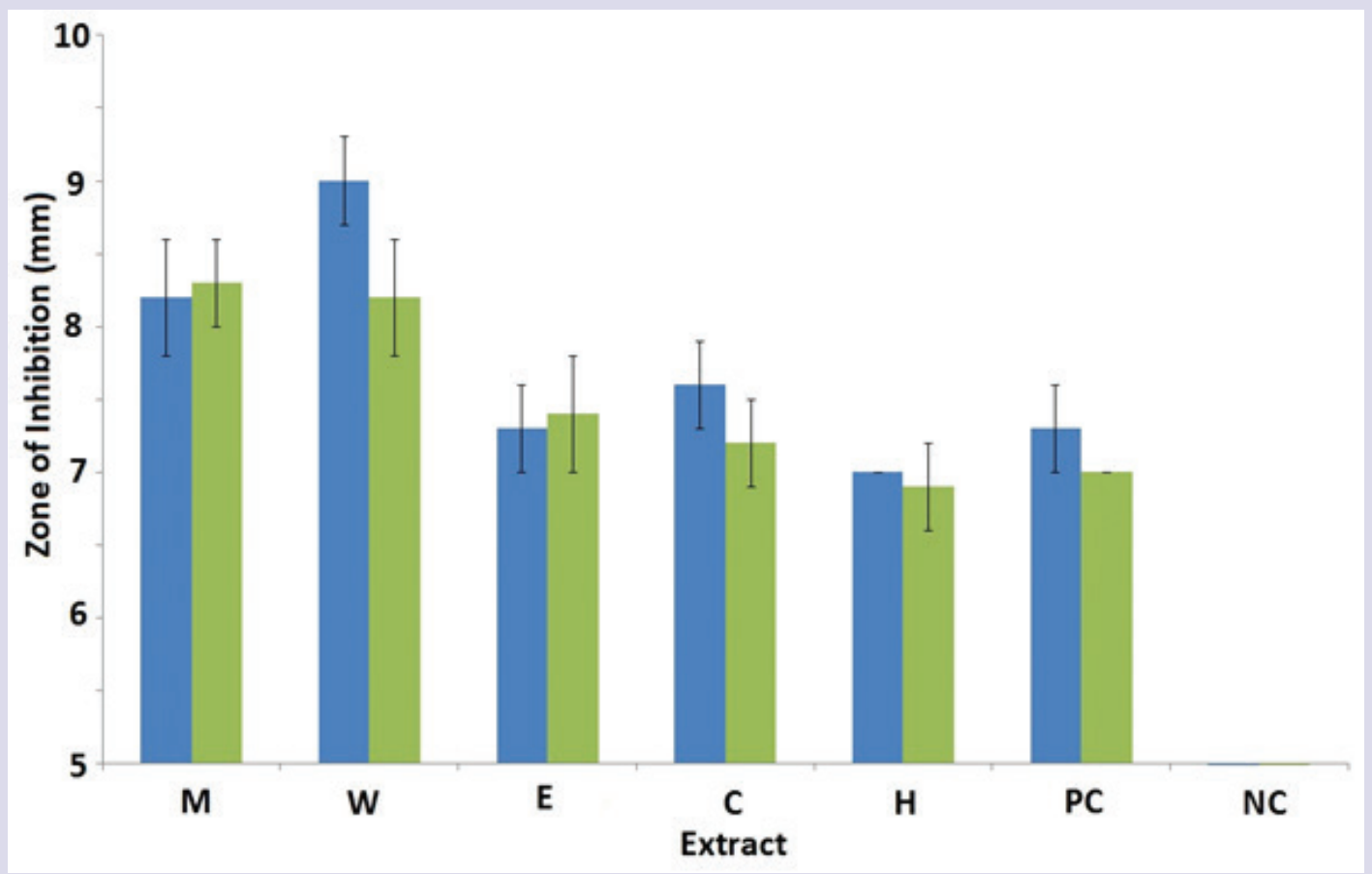

Figure 2: Antibacterial activity of the frankincense extracts against $K$. pneumoniae measured as zones of inhibition ( $\mathrm{mm}$ ). The blue bars represent the inhibitory activity against the reference strain (ATCC:213488) and the green bars represent the zones of inhibition against the clinical strain. $\mathrm{M}=$ methanolic extract; $\mathrm{W}=$ water extract; $\mathrm{E}=$ ethyl acetate extract; $\mathrm{C}=$ chloroform extract; $\mathrm{H}=$ hexane extract; $\mathrm{NC}=0.5 \%$ DMSO; $\mathrm{PC}=$ ampicillin $(10 \mu \mathrm{g})$ control. Results are expressed as mean zones of inhibition \pm SEM.

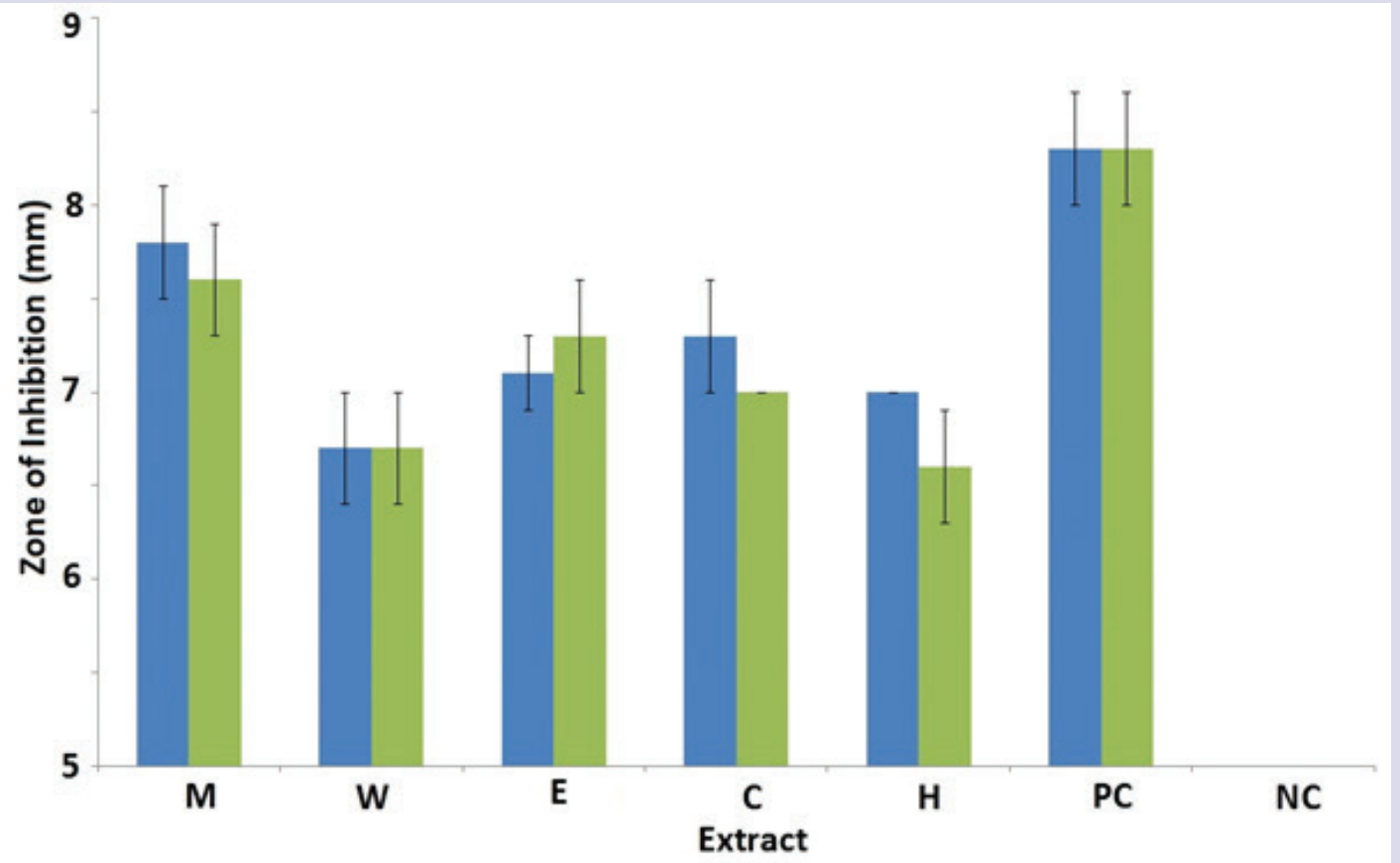

Figure 3: Antibacterial activity of the frankincense extracts against $A$. baylyi measured as zones of inhibition ( $\mathrm{mm}$ ). The blue bars represent the inhibitory activity against the reference strain (ATCC:33304) and the green bars represent the zones of inhibition against the clinical strain. $\mathrm{M}=$ methanolic extract; $\mathrm{W}=$ water extract; $\mathrm{E}=$ ethyl acetate extract; $\mathrm{C}=$ chloroform extract; $\mathrm{H}=$ hexane extract; $\mathrm{NC}=0.5 \%$ DMSO; $\mathrm{PC}=$ ampicillin $(10 \mu \mathrm{g})$ control. Results are expressed as mean zones of inhibition $\pm \mathrm{SEM}$. 


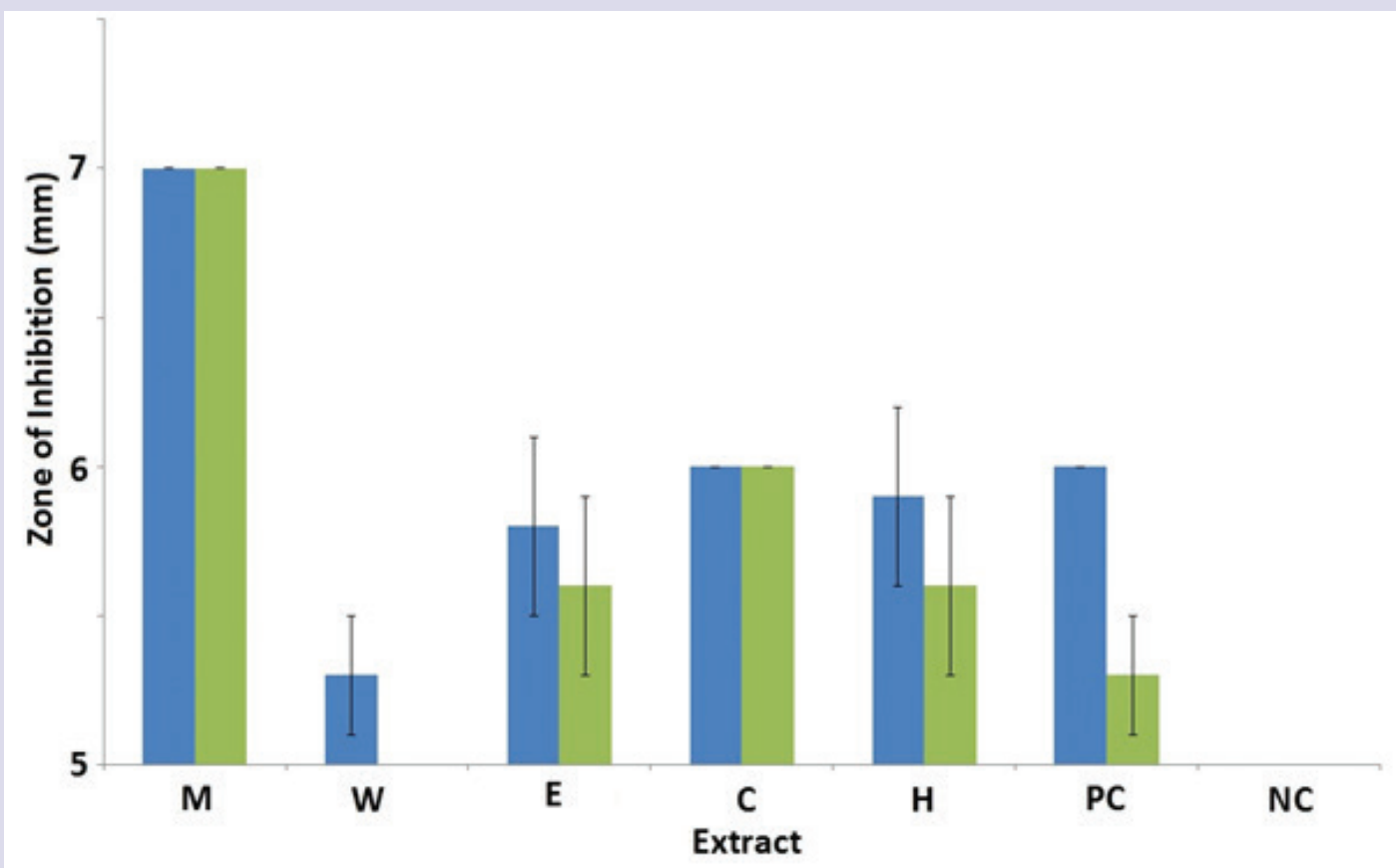

Figure 4: Antibacterial activity ofthe frankincense extracts against $P$. aeruginosa measured as zones of inhibition ( $\mathrm{mm}$ ). The blue bars represent the inhibitory activity against the reference strain (ATCC:39324) and the green bars represent the zones of inhibition against the clinical strain $\mathrm{M}=$ methanolic extract; $\mathrm{W}=$ water extract; $\mathrm{E}=$ ethyl acetate extract; $\mathrm{C}=$ chloroform extract; $\mathrm{H}=$ hexane extract; $\mathrm{NC}=0.5 \%$ DMSO; $\mathrm{PC}=$ ampicillin $(10 \mu \mathrm{g})$ control. Results are expressed as mean zones of inhibition $\pm \mathrm{SEM}$.

Table 3: Minimum bacterial growth inhibitory concentration $(\mu \mathrm{g} / \mathrm{mL})$ of the frankincense extracts and $L C_{50}$ values $(\mu \mathrm{g} / \mathrm{mL})$ in the Artemia nauplii bioassay

\begin{tabular}{|c|c|c|c|c|c|c|c|}
\hline & Bacterial Species & Strain & $M$ & W & $E$ & C & $\mathrm{H}$ \\
\hline \multirow{8}{*}{ 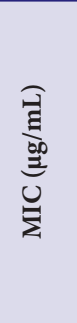 } & \multirow{2}{*}{ P. mirabilis } & ATCC:21721 & 59.6 & 1000 & 8910 & 3391 & $>10,000$ \\
\hline & & Clinical isolate & 123.8 & 1000 & 9235 & 3728 & $>10,000$ \\
\hline & \multirow{2}{*}{ K. pneumoniae } & ATCC:213488 & 1083.5 & 148 & $>10,000$ & 7697 & $>10,000$ \\
\hline & & Clinical isolate & 927.3 & 75.2 & $>10,000$ & 8323 & $>10,000$ \\
\hline & \multirow{2}{*}{ A. baylyi } & ATCC:33304 & $>10,000$ & 4313 & $>10,000$ & $>10,000$ & $>10,000$ \\
\hline & & Clinical isolate & $>10,000$ & 4313 & $>10,000$ & $>10,000$ & $>10,000$ \\
\hline & \multirow{2}{*}{ P. aeruginosa } & ATCC:39324 & $>10,000$ & $>10,000$ & $>10,000$ & $>10,000$ & $>10,000$ \\
\hline & & Clinical isolate & $>10,000$ & $>10,000$ & $>10,000$ & $>10,000$ & $>10,000$ \\
\hline 记 & A. franciscana & nauplii & $>10,000$ & 4406 & $>10,000$ & $>10,000$ & $>10,000$ \\
\hline
\end{tabular}

Numbers indicate the mean MIC and $\mathrm{LC}_{50}$ values of triplicate determinations. - indicates no inhibition.

approximately equally susceptible to each extract. The methanolic extract was the most potent growth inhibitor, with zones of inhibition of $7.8 \pm 0.3$ and $7.6 \pm 0.3 \mathrm{~mm}$ respectively.In addition, the aqueous, ethyl acetate, chloroform and hexane extracts all inhibited A. baylyi growth, with zones of inhibition of $6.6-7.3 \mathrm{~mm}$. However, it is noteworthy that these zones of inhibition are indicative of only weak growth inhibition, and are substantially less than the inhibition by the ampicillin control (8.3 mm for both strains).

Both reference and clinical strains of $P$. aeruginosa were also inhibited by all of the frankincense extracts, albeit with relatively small zones of inhibition (Figure 4). The methanolic extract was the best $P$. aeruginosa growth inhibitor, although it only produced zones of inhibition of $7 \mathrm{~mm}$. All other frankincense extracts gave substantially lower zones of inhibition. The aqueous extract was a particularly weak growth inhibitor. Indeed, the aqueous extract only inhibited growth of the reference strain, whilst growth of the clinical $P$. aeruginosa isolate was completely uninhibited. However, it is noteworthy that both $P$. aeruginosa strains were also resistant to the antibiotic control (10 $\mu \mathrm{g}$ ampicillin), with only small zones of inhibition also noted $(6.0 \pm 0$ and $5.3 \pm 0.3 \mathrm{~mm}$ for the reference and clinical strains respectively). 
The antimicrobial efficacy was further quantified by determining the MIC values for each extract against the microbial species which were determined to be susceptible.The methanolic and aqueous extracts were most effective at inhibiting the growth, particularly of $P$. mirabilis and K. pneumoniae (Table 3), with MIC values $\leq 1000 \mu \mathrm{g} / \mathrm{mL}(\leq 10 \mu \mathrm{g}$ impregnated in the disc), indicating the potential of these extracts in controlling rheumatoid arthritis and ankylosing spondylitis. The methanolic extract was particularly potent, with MIC values of 59.6 and $123.8 \mu \mathrm{g} / \mathrm{mL}$ (approximately 0.6-1.3 $\mu \mathrm{g}$ impregnated in the disc) against the reference and clinical $P$. mirabilis strains respectively.As $P$. mirabilis has been identified as a trigger of rheumatoid arthritis, methanolic frankincense extracts have potential for the prevention of this disease in genetically susceptible individuals. The methanolic extract also was a good inhibitor of K. pneumoniae growth with MIC values of 927-1084 $\mu \mathrm{g} / \mathrm{mL}$ (approximately $10 \mu \mathrm{g}$ impregnated in the disc). In contrast, the aqueous extract was a more potent inhibitor of K. pneumoniae growth (MIC values of 148 and $75.2 \mu \mathrm{g} / \mathrm{mL}$ for the reference and clinical strains respectively). The aqueous extract was also a good inhibitor of $P$. mirabilis growth, with MIC values of $1000 \mu \mathrm{g} / \mathrm{mL}$ for both strains of the bacterium. Notably, the aqueous extract also showed moderate inhibitory activity against one of the bacterial triggers of multiple sclerosis (A. baylii, MIC values of approximately $4300 \mu \mathrm{g} / \mathrm{mL}$ against both strains). The chloroform extract also gave moderate growth inhibition against $P$. mirabilis growth, with MIC values of approximately $3500 \mu \mathrm{g} / \mathrm{mL}$ for both strains. Low growth inhibition was noted for all other extract/bacterium combinations, with MIC values $>5000 \mu \mathrm{g} / \mathrm{mL}$.

\section{Quantification of toxicity}

All extracts were initially screened undiluted in the Artemia nauplii bioassay (Figure 5). For comparison, the reference toxin potassium dichromate $(1000 \mu \mathrm{g} / \mathrm{mL})$ was also tested. The potassium dichromate reference toxin was rapid in its onset of mortality, inducing nauplii death within the first 3 hours of exposure and 100\% mortality was evident following 4-5 hours (results not shown). Similarly, all frankincense extracts induced $100 \%$ mortality within $24 \mathrm{~h}$.

To further quantify the effect of toxin concentration on the induction of mortality, the extracts were serially diluted in artificial seawater to test across a range of concentrations in the Artemia nauplii bioassay. Table 3 shows the $\mathrm{LC}_{50}$ values of the frankincense extracts towards $A$. franciscana. All frankincense extracts were determined to be nontoxic, with $\mathrm{LC}_{50}$ values substantially greater than $1000 \mu \mathrm{g} / \mathrm{mL}$ following $24 \mathrm{~h}$ exposure. Extracts with an $\mathrm{LC}_{50}$ of greater than $1000 \mu \mathrm{g} / \mathrm{mL}$ towards $A r$ temia nauplii have previously been defined as being nontoxic. ${ }^{33}$

\section{Non-targeted GC-MS headspace analysis of the frankincense extracts}

As the methanolic and aqueous frankincense extracts had the greatest bacterial growth inhibitory efficacy (as determined by MIC; Table 3), they were deemed the most promising extracts for further phytochemical analysis. Optimised GC-MS parameters were developed and used to examine the phytochemical composition of these extracts. The resultant gas chromatograms for the methanolic and aqueous extracts are presented in Figures $6 \mathrm{a}$ and Figure $6 \mathrm{~b}$ respectively. Major peaks were present in both the methanolic and aqueous extracts at approximately 15.3, 17.5, 19.1, 20.3, 21.0 and $21.4 \mathrm{~min}$. A further major peak was also noted in the aqueous frankincense extract at $15.9 \mathrm{~min}$, which corresponded to a minor peak in the methanolic extract. Numerous overlapping peaks were also evident throughout all stages of the chromatograms. In total, 74 unique mass signals were noted for the frankincense methanolic and aqueous extracts (Table 4). Putative empirical formulas and identifications were achieved for all of these compounds.

\section{DISCUSSION}

Plant remedies are becoming increasingly sought after in the treatment of a myriad of diseases and disorders due both to their perception of greater safety than synthetic drugs, and the failure of current drug regimens to effectively treat many diseases. This is especially true for the autoimmune inflammatory diseases. The current treatments utilising disease modifying anti-rheumatic drugs (DMARDs) to alleviate the symptoms of these diseases and/or alter the disease progression are not entirely effective and have been associated with numerous adverse effects. ${ }^{34}$ Furthermore, many of the current treatments are aimed at treating the symptoms without addressing the underlying causes and pathogenic mechanisms. A better understanding of the mechanisms for initiation and progression of the autoimmune inflammatory diseases is important for developing new drugs to target specific processes and thus more effectively treat autoimmune inflammatory diseases.

The studies reported here examined the ability of Boswelliacarteri resin (frankincense) extracts to block microbial triggers of 3 autoimmune inflammatory disorders (Proteus mirabilis: rheumatoid arthritis; K. pneumonia: ankylosing spondylitis; Acinitobacterbaylyi and Pseudomonas aeruginosa: multiple sclerosis). The methanolic extract was identified as being a particularly potent inhibitor of $P$. mirabilis (MIC values of 59.6 and $123.8 \mu \mathrm{g} / \mathrm{mL}$ for the reference and clinical strains respecitively).Thus this extract has potential for the development of rheumatoid arthritis inhibitory therapies. Interestingly, as previous studies have also demonstrated that $B$. carterii extracts regulate cytokine production, ${ }^{11}$ the methanolic frankincense extract (which was prepared using B. carterii resin), may well have similar properties and further studies are required to test this. If our extracts are subsequently found to modulate cytokine production, they may prove to be particularly useful for individuals suffering from rheumatoid arthritis, as they would provide both preventative and treatment mechanisms.

The aqueous extract also displayed good $P$. mirabilis growth inhibitory properties (MIC values of $1000 \mu \mathrm{g} / \mathrm{mL}$ for both the reference and clinical strains), indicating that it may also be useful in the prevention of rheumatoid arthritis. However, the MIC values for the aqueous extract were substantially higher than the methanolic extract. In contrast, the aqueous extract appeared to have greater potential for the prevention and treatment of ankylosing spondylitis. The aqueous frankincense extract had MIC values of 148 and $75.2 \mu \mathrm{g} / \mathrm{mL}$ for reference and clinical K. pnuemoniae strains respecitively (compared to approximately $1000 \mu \mathrm{g} / \mathrm{mL}$ for the methanolic extract). As previously discussed for rheumatoid arthritis, it is possible that the aqueous extract may also have further effects on other phases of ankylosing spondylitis disease etiology. Indeed, it is possible that the extract may also modulate cytokine production and therefore also block later inflammatory disease events, although this has yet to be tested.

GC-MS headspace analysis of the methanolic and aqueous frankincense extracts detected a number of interesting compounds, including a wide diversity of terpenoids. Monoterpenoids were particularly prevalent, with approximately 35 monoterpenoids putatively identified. The monoterpoids 2,4(10)-thujadiene (Figure 7a1), cis-p-mentha-2, 8-dien-1-ol (Figure7a2), cineole (Figure7a4), a-pinene (Figure 7a6), 1,2-dimethyl-1-cyclohexene (Figure 7b1), thujone (Figure 7b2), (1S,3S,4S,5R)-(+)-3-thujanol (Figure 7b3), (+)-sabinol (Figure 7b4), L-camphor (Figure 7b5), a-phellandren-8-ol (Figure 7b6), sabina ketone (Figure 7c1), pinocarvone (Figure 7c2), endo-borneol (Figure 7c3), verbenone (Figure 7c4), terpinene-4-ol (Figure 7c5), cis-m-menth8-ene(Figure 7c6), a-terpineol (Figure 7d1), (-)-myrtenol (Figure 7d2), sabinyl acetate (Figure 7d3), 2-pinen-7-one (Figure 7d4), 3,4-dimethylbenzaldehyde (Figure 7d5), p-cumic aldehyde (Figure 7e2), D-carvone (Figure 7e3), p-cymen-7-ol (Figure 7e5) and thymol (Figure 7e6) 


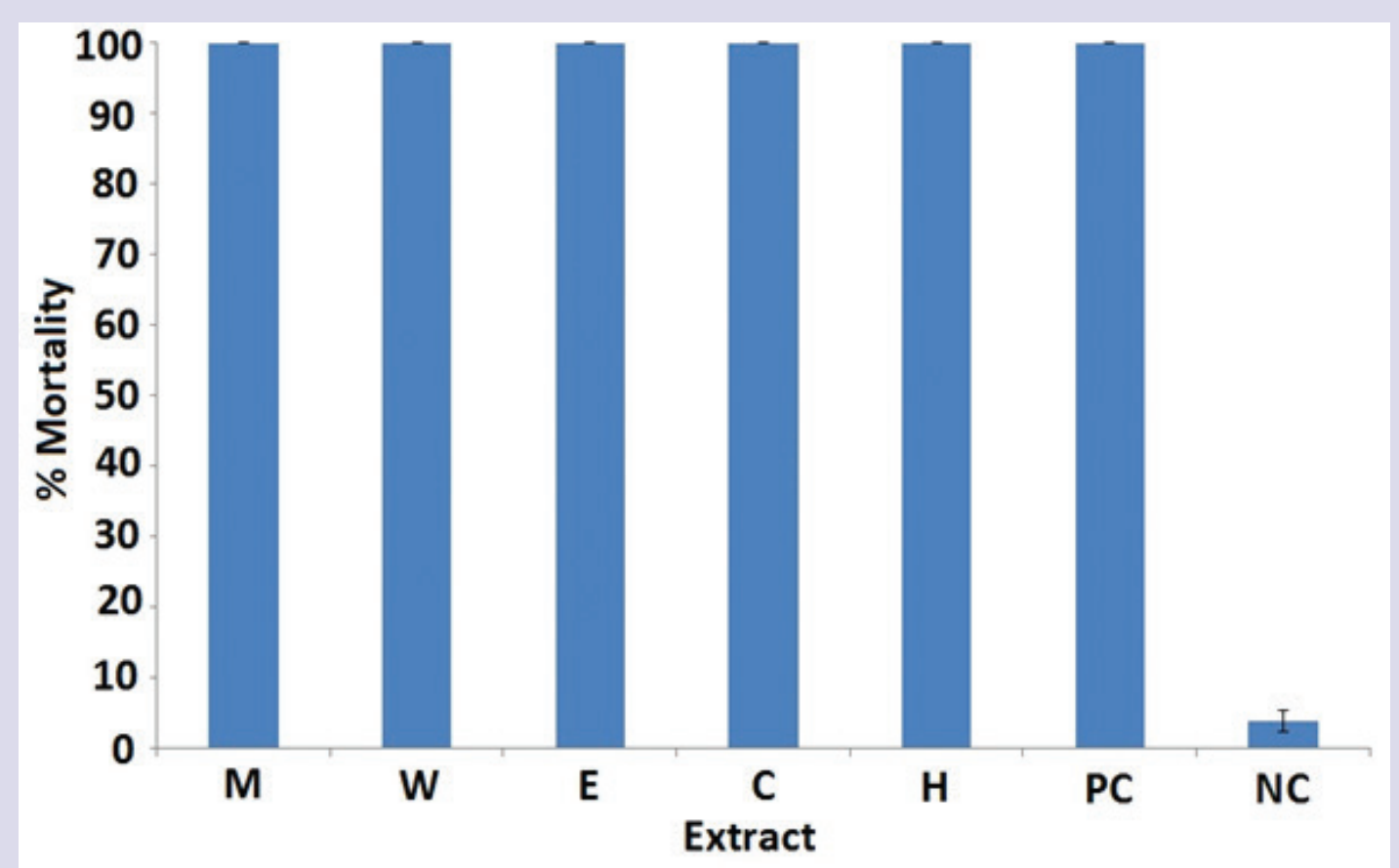

Figure 5: The lethality of the undiluted frankincense extracts and the potassium dichromate control $(1000 \mu \mathrm{g} / \mathrm{mL})$ towards $\mathrm{Ar}$ temia nauplii. $\mathrm{M}=$ methanolic extract; $\mathrm{W}=$ water extract; $\mathrm{E}=$ ethyl acetate extract; $\mathrm{C}=$ chloroform extract; $\mathrm{H}=$ hexane extract; $\mathrm{PC}=$ positive control $(1000 \mu \mathrm{g} / \mathrm{ml}$ potassium dichromate); $\mathrm{NC}=$ negative (seawater) control. All tests were performed in at least triplicate and the results are expressed as mean \pm SEM.

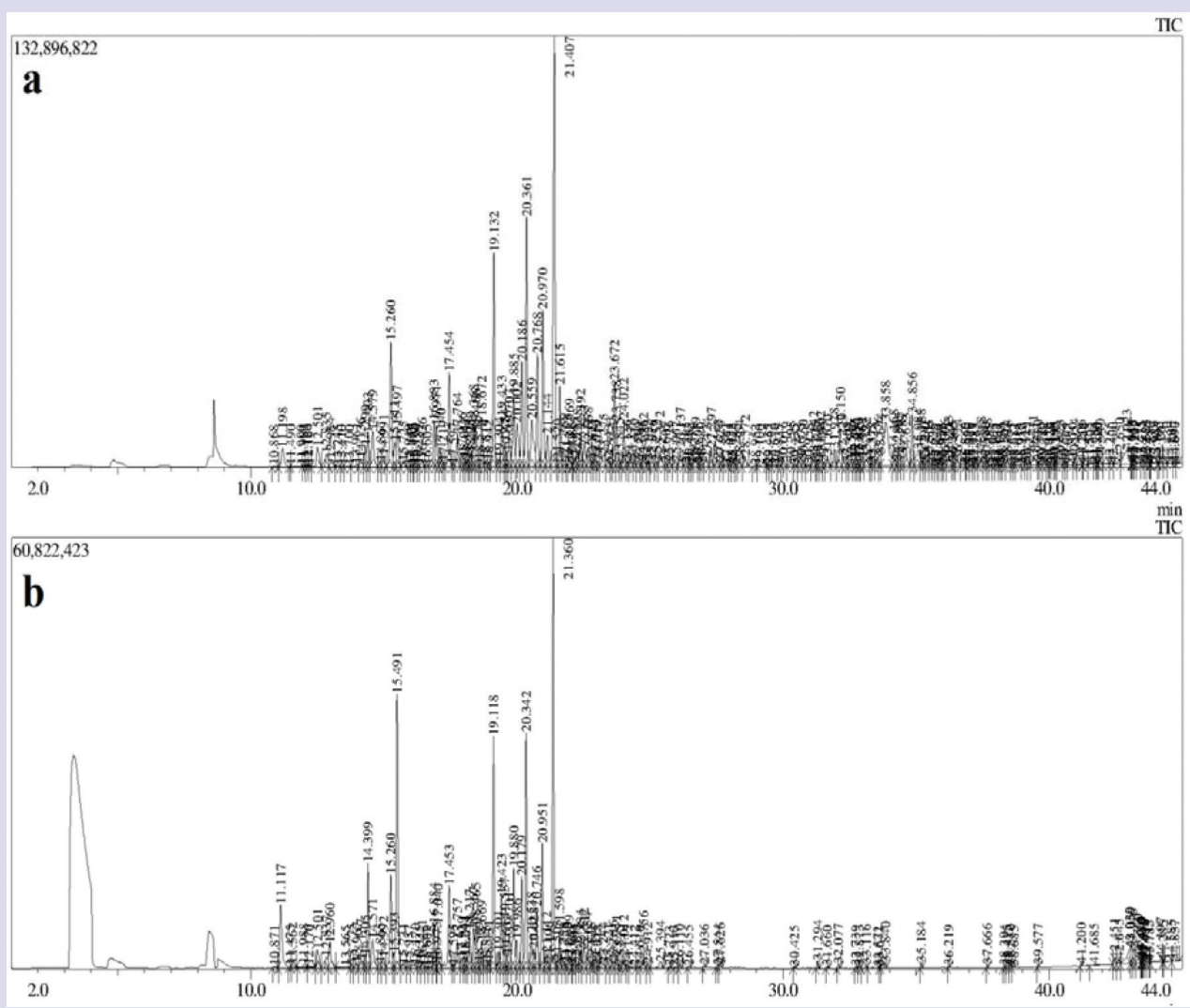

Figure 6: Head space gas chromatograms of $0.5 \mu \mathrm{L}$ injections of (a) methanolic and (b) aqueous frankincense extracts. The extracts were dried and resuspended in methanol for analysis. 
Table 4: GC-MS analysis of the frankincense methanolic and aqueous extracts, elucidation of empirical formulas and putative identification of each compound

\begin{tabular}{|c|c|c|c|c|c|}
\hline \multirow[t]{2}{*}{ Putative Identification } & \multirow[t]{2}{*}{ Empirical Formula } & \multirow[t]{2}{*}{ Molecular Mass (Da) } & \multirow{2}{*}{$\begin{array}{l}\text { Retention Time } \\
\text { (min) }\end{array}$} & \multicolumn{2}{|c|}{$\begin{array}{l}\text { Relative Abundance } \\
\text { (\% Area) }\end{array}$} \\
\hline & & & & $M$ & $\mathbf{W}$ \\
\hline 1,3,5,5-Tetramethyl-1,3-cyclohexadiene & $\mathrm{C}_{10} \mathrm{H}_{16}$ & 136 & 10.868 & 0.04 & 0.07 \\
\hline Methyl N-hydroxybenzenecarboximidoate & $\mathrm{C}_{8} \mathrm{H}_{9} \mathrm{NO}_{2}$ & 151 & 11.198 & 0.88 & 3.53 \\
\hline 2,4(10)-Thujadiene (isomer 1 ) & $\mathrm{C}_{10} \mathrm{H}_{14}$ & 134 & 12.501 & 1.21 & 0.88 \\
\hline $\begin{array}{l}\text { CompName:(1S,3S,5S)-1-Isopropyl-4- } \\
\text { methylenebicyclo [3.1.0] hexan-3-yl acetate }\end{array}$ & $\mathrm{C}_{12} \mathrm{H}_{18} \mathrm{O}_{2}$ & 194 & 12.835 & 0.47 & - \\
\hline 6-Methyl-5-heptene-2-one & $\mathrm{C}_{8} \mathrm{H}_{14} \mathrm{O}$ & 126 & 13.961 & 0.08 & 0.2 \\
\hline cis-p-Mentha-2,8-dien-1-ol & $\mathrm{C}_{10} \mathrm{H}_{16} \mathrm{O}$ & 152 & 14.136 & 0.3 & 0.46 \\
\hline 2-Menthene & $\mathrm{C}_{10} \mathrm{H}_{18}$ & 138 & 14.299 & 0.55 & - \\
\hline Myrtenylisovalerate & $\mathrm{C}_{15} \mathrm{H}_{24} \mathrm{O}_{2}$ & 236 & 14.579 & 1.2 & 1.54 \\
\hline $\begin{array}{l}\text { Bicyclo [3.1.0] hexan-2-ol, 2-methyl-5-(1- } \\
\text { methylethyl)-, (1.alpha.,2.alpha.,5.alpha.)- }\end{array}$ & $\mathrm{C}_{10} \mathrm{H}_{18} \mathrm{O}$ & 154 & 14.991 & 0.39 & 0.55 \\
\hline p-Cymene & $\mathrm{C}_{10} \mathrm{H}_{14}$ & 134 & 15.26 & 3.53 & 3.41 \\
\hline Cineole & $\mathrm{C}_{10} \mathrm{H}_{18} \mathrm{O}$ & 154 & 15.497 & 1.1 & 9.34 \\
\hline$\gamma$-Terpineol & $\mathrm{C}_{10} \mathrm{H}_{18} \mathrm{O}$ & 154 & 15.94 & 0.02 & - \\
\hline a.-Pinene & $\mathrm{C}_{10} \mathrm{H}_{16}$ & 136 & 16.436 & 0.21 & 0.25 \\
\hline Toluene & $\mathrm{C}_{7} \mathrm{H}_{8}$ & 92 & 16.971 & 0.93 & - \\
\hline 1,1-Dimethyl-decyl-mercaptan & $\mathrm{C}_{12} \mathrm{H}_{26} \mathrm{~S}$ & 202 & 17.219 & 0.12 & - \\
\hline p-Cymenene & $\mathrm{C}_{10} \mathrm{H}_{12}$ & 132 & 17.454 & 2.38 & - \\
\hline Linalool & $\mathrm{C}_{10} \mathrm{H}_{18} \mathrm{O}$ & 154 & 17.764 & 0.82 & 1 \\
\hline 1,2-Dimethyl-1-cyclohexene & $\mathrm{C}_{8} \mathrm{H}_{14}$ & 110 & 18.011 & 0.19 & 0.33 \\
\hline Thujone & $\mathrm{C}_{10} \mathrm{H}_{16} \mathrm{O}$ & 152 & 18.368 & 1.04 & 1.41 \\
\hline Dehydrosabinene ketone & $\mathrm{C}_{9} \mathrm{H}_{12} \mathrm{O}$ & 136 & 18.466 & 0.91 & 1.37 \\
\hline Camphen-6-ol & $\mathrm{C}_{10} \mathrm{H}_{16} \mathrm{O}$ & 152 & 18.672 & 1.12 & 0.8 \\
\hline $2,4(10)$-Thujadiene (isomer 2 ) & $\mathrm{C}_{10} \mathrm{H}_{14}$ & 134 & 18.819 & 0.16 & - \\
\hline$(1 S, 3 S, 4 S, 5 R)-(+)-3-T h u j a n o l$ & $\mathrm{C}_{10} \mathrm{H}_{18} \mathrm{O}$ & 154 & 18.942 & 0.12 & 0.23 \\
\hline$(+)$-Sabinol & $\mathrm{C}_{10} \mathrm{H}_{16} \mathrm{O}$ & 152 & 19.132 & 5.02 & 6.89 \\
\hline L-camphor & $\mathrm{C}_{10} \mathrm{H}_{16} \mathrm{O}$ & 152 & 19.304 & 0.22 & 0.51 \\
\hline a-Phellandren-8-ol & $\mathrm{C}_{10} \mathrm{H}_{16} \mathrm{O}$ & 152 & 19.433 & 1.19 & 2.35 \\
\hline Sabina ketone & $\mathrm{C}_{9} \mathrm{H}_{14} \mathrm{O}$ & 138 & 19.707 & 0.9 & 1.13 \\
\hline Pinocarvone & $\mathrm{C}_{10} \mathrm{H}_{14} \mathrm{O}$ & 150 & 19.885 & 1.96 & 3.48 \\
\hline endo-Borneol & $\mathrm{C}_{10} \mathrm{H}_{18} \mathrm{O}$ & 154 & 20.002 & 1.48 & 0.94 \\
\hline Verbenone & $\mathrm{C}_{10} \mathrm{H}_{14} \mathrm{O}$ & 154 & 20.186 & 2.63 & 2.61 \\
\hline Terpinen-4-ol & $\mathrm{C}_{10} \mathrm{H}_{18} \mathrm{O}$ & 154 & 20.361 & 5.79 & 6.93 \\
\hline p-Cymen-8-ol & $\mathrm{C}_{10} \mathrm{H}_{14} \mathrm{O}$ & 150 & 20.559 & 2.04 & 1.16 \\
\hline cis-m-Menth-8-ene & $\mathrm{C}_{11} \mathrm{H}_{20}$ & 138 & 20.63 & - & 0.59 \\
\hline$\alpha$-Terpineol & $\mathrm{C}_{10} \mathrm{H}_{18} \mathrm{O}$ & 154 & 20.768 & 2.8 & 1.91 \\
\hline (-)-Myrtenol (isomer 1) & $\mathrm{C}_{10} \mathrm{H}_{16} \mathrm{O}$ & 152 & 20.97 & 3.9 & 3.57 \\
\hline Sabinyl acetate & $\mathrm{C}_{12} \mathrm{H}_{18} \mathrm{O} 2$ & 194 & 21.144 & 0.94 & 0.49 \\
\hline 2-Pinen-7-one & $\mathrm{C}_{10} \mathrm{H}_{14} \mathrm{O}$ & 150 & 21.407 & 11.93 & 12,24 \\
\hline 3,4-Dimethylbenzaldehyde & $\mathrm{C}_{9} \mathrm{H}_{10} \mathrm{O}$ & 134 & 21.52 & 0.12 & 0.2 \\
\hline Carveol & $\mathrm{C}_{10} \mathrm{H}_{16} \mathrm{O}$ & 152 & 21.615 & 2.97 & 1.09 \\
\hline cis-p-mentha-1(7),8-dien-2-ol & $\mathrm{C}_{10} \mathrm{H}_{16} \mathrm{O}$ & 152 & 21.955 & - & 0.46 \\
\hline 4(10)-Thujen-3-ol, acetate & $\mathrm{C}_{12} \mathrm{H}_{18} \mathrm{O}_{2}$ & 194 & 22.185 & 0.25 & - \\
\hline p-Cumic aldehyde & $\mathrm{C}_{10} \mathrm{H}_{12} \mathrm{O}$ & 148 & 22.278 & 0.37 & 0.14 \\
\hline D-Carvone & $\mathrm{C}_{10} \mathrm{H}_{14} \mathrm{O}$ & 150 & 22.392 & 0.78 & 0.49 \\
\hline (-)-Bornyl acetate & $\mathrm{C}_{12} \mathrm{H}_{20} \mathrm{O}_{2}$ & 196 & 23.672 & 2.01 & - \\
\hline p-Cymen-7-ol & $\mathrm{C}_{10} \mathrm{H}_{14} \mathrm{O}$ & 150 & 23.738 & 1.08 & 0.51 \\
\hline Thymol & $\mathrm{C}_{10} \mathrm{H}_{14} \mathrm{O}$ & 150 & 24.022 & 1.07 & 0.38 \\
\hline (-)-Myrtenol (isomer 2) & $\mathrm{C}_{10} \mathrm{H}_{16} \mathrm{O}$ & 152 & 24.923 & 0.15 & 0.12 \\
\hline Limonene oxide & $\mathrm{C}_{10} \mathrm{H}_{16} \mathrm{O}$ & 152 & 25.252 & 0.13 & - \\
\hline
\end{tabular}




\begin{tabular}{|c|c|c|c|c|c|}
\hline $\begin{array}{c}\text { (1S,3S,4S,5R)-1-Isopropyl-4-methylbicyclo [3.1.0] } \\
\text { hexan-3-ol }\end{array}$ & $\mathrm{C}_{10} \mathrm{H}_{18} \mathrm{O}$ & 144 & 25.605 & 0.08 & - \\
\hline $\begin{array}{l}\text { Propanoic acid, 2-methyl-, 3-hydroxy-2,2,4- } \\
\text { trimethylpentyl ester }\end{array}$ & $\mathrm{C}_{12} \mathrm{H}_{24} \mathrm{O}_{3}$ & 216 & 26.465 & 0.09 & 0.04 \\
\hline Copaene & $\mathrm{C}_{15} \mathrm{H}_{24}$ & 204 & 26.719 & 0.34 & - \\
\hline Guaia-1(10),11-diene & $\mathrm{C}_{15} \mathrm{H}_{24}$ & 204 & 27.297 & 0.53 & - \\
\hline 1-Ethyl-5,5-dimethyl-1,3-cyclopentadiene & $\mathrm{C}_{9} \mathrm{H}_{14}$ & 122 & 28.364 & 0.17 & - \\
\hline Caryophyllene & C15 H24 & 204 & 28.572 & 0.31 & - \\
\hline 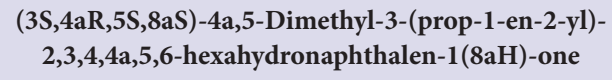 & $\mathrm{C}_{15} \mathrm{H}_{22} \mathrm{O}$ & 218 & 29.67 & 0.07 & - \\
\hline cis-muurola-3,5-diene & $\mathrm{C}_{15} \mathrm{H}_{24}$ & 204 & 29.825 & 0.02 & - \\
\hline Humulene & $\mathrm{C}_{15} \mathrm{H}_{24}$ & 204 & 30.016 & 0.1 & - \\
\hline $\begin{array}{c}\text { Naphthalene, 1,2,3,5,6,7,8,8a-octahydro-1,8a- } \\
\text { dimethyl-7-(1-methylethenyl)-, [1R-(1.alpha.,7. } \\
\text { beta.,8a.alpha.)]- }\end{array}$ & $\mathrm{C}_{15} \mathrm{H}_{24}$ & 204 & 30.298 & 0.15 & - \\
\hline epsilon-Muurolene & $\mathrm{C}_{15} \mathrm{H}_{24}$ & 204 & 30.75 & 0.14 & - \\
\hline Eudesma-4(14),11-diene & $\mathrm{C}_{15} \mathrm{H}_{24}$ & 204 & 31.142 & 0.37 & - \\
\hline (+)-Ledene & $\mathrm{C}_{15} \mathrm{H}_{24}$ & 204 & 31.402 & 0.37 & - \\
\hline 2,4-Di-tert-butylphenol & $\mathrm{C}_{14} \mathrm{H}_{22} \mathrm{O}$ & 206 & 31.67 & 0.25 & 0.04 \\
\hline$\gamma$-Muurolene & $\mathrm{C}_{15} \mathrm{H}_{24}$ & 204 & 31.928 & 0.41 & - \\
\hline Ethyl 4-ethoxybenzoate & $\mathrm{C}_{11} \mathrm{H}_{14} \mathrm{O}_{3}$ & 194 & 32.15 & 1.08 & 0.49 \\
\hline Cubenene & $\mathrm{C}_{15} \mathrm{H}_{24}$ & 204 & 32.408 & 0.05 & - \\
\hline Sabinylisobutanoate & $\mathrm{C}_{14} \mathrm{H}_{22} \mathrm{O}_{2}$ & 194 & 32.695 & 0.13 & - \\
\hline $\begin{array}{l}\text { 5-Cyclodecen-1-ol, 4,10-bis(methylene)-7-(1- } \\
\text { methylethyl)-, (1R,5E,7S)- }\end{array}$ & $\mathrm{C}_{15} \mathrm{H}_{24} \mathrm{O}$ & 220 & 32.962 & 0.26 & - \\
\hline Epicubenol & $\mathrm{C}_{15} \mathrm{H}_{26} \mathrm{O}$ & 222 & 34.623 & 1.14 & - \\
\hline tau-Cadinol & $\mathrm{C}_{15} \mathrm{H}_{26} \mathrm{O}$ & 222 & 34.856 & 1.11 & - \\
\hline $\begin{array}{c}\text { 2-((2R,4aR,8aS)-4a-Methyl-8- } \\
\text { methylenedecahydronaphthalen-2-yl)prop-2-en- } \\
\text { 1-ol }\end{array}$ & $\mathrm{C}_{15} \mathrm{H}_{24} \mathrm{O}$ & 220 & 35.431 & 0.13 & - \\
\hline Azunol & $\mathrm{C}_{15} \mathrm{H}_{18}$ & 198 & 35.505 & 0.1 & - \\
\hline a-Phellandrene & $\mathrm{C}_{10} \mathrm{H}_{16}$ & 136 & 37.448 & 0.18 & - \\
\hline Squalene & $\mathrm{C}_{30} \mathrm{H}_{50}$ & 410 & 39.411 & 0.42 & - \\
\hline 1-Propylpentyl laurate & $\mathrm{C}_{20} \mathrm{H}_{40} \mathrm{O}_{2}$ & 312 & 40.954 & 0.1 & - \\
\hline
\end{tabular}

The relative abundance expressed in this table is a measure of the area under the peak expressed as a $\%$ of the total area under all chromatographic peaks.

were detected in both the methanolic and aqueous extracts. Seven further monoterpenoids (myrtenylisovalerate (Figure 7a3), $\gamma$-terpineol (Figure 7a5), 4(10)-thujen-3-ol, acetate(Figure 7e1), (-)-bornyl acetate (Figure 7e4), limonene oxide (Figure 7f1), sabinylisobutanoate (Figure 7f2), $\alpha$-phellandrene (Figure $7 \mathrm{f} 3)$ ) were detected only in the methanolic extract, whilst cis-p-mentha-1(7),8-dien-2-ol (Figure 7d6) was only detected in the aqueous extract.

Monoterpenes have been reported to exert a wide variety of biological effects including antibacterial, antifungal, anti-inflammatory and antitumour activities ${ }^{35}$ and therefore may contribute to the growth inhibitory activity against the bacterial triggers of the autoimmune diseases reported here. Indeed, many of the monoterpenoids putatively identified in our study have been previously reported to have potent broad spectrum antibacterial activity. ${ }^{35} \mathrm{~A}$ wide variety of monoterpenoids including camphor, carvone, cineole, borneol, menthone, pinene, terpinene, as well as their derivatives, inhibit the growth of an extensive panel of pathogenic and food spoilage bacteria. ${ }^{36}$ Interestingly, several of these monoterpenoids have also been reported to suppress NF- $\kappa$ Bsignaling (the major regulator of inflammatory diseases). ${ }^{37-40}$ Thus, the terpene components may have a pleuripotent mechanism in blocking the autoimmune inflammatory diseases and relieving its symptoms by acting on both the initiator and downstream inflammatory stages of the disease. Further phytochemical evaluation studies and bioactivity driven isolation of active components is required to further evaluate the mechanism(s) of bacterial growth inhibition.

Several sesquiterpenoids including copaene (Figure 8a), guaia-1(10), 11-diene (Figure 8b), caryophyllene (Figure 8c), cis-muurola-3, 5-diene (Figure 8d), humulene (Figure 8e), epsilon-muurolene (Figure 8f), eudesma-4(14), 11-diene (Figure 8g), (+)-ledene (Figure 8h), $\gamma$-muurolene (Figure 8i), cubenene (Figure 8j), epicubenol (Figure 8k), tau-cadinol (Figure 81), azunol Figure $8 \mathrm{~m}$ ) were also detected in the methanolic and aqueous frankincense extracts. Previous studies have reported bacterial growth inhibitory activities for many sesquiterpenoids including cadinol, ${ }^{41}$ caryophyllene, ${ }^{42}$ copaene, epicubenol and cubenene. $^{43}$

An important consideration of any metabolomic technique is that it will not detect all compounds in a complex mixture, but instead will only detect a portion of them. This is not necessarily a problem when a directed/ biased study is undertaken to detect a particular compound or class of compounds and the separation and detection conditions can be optimised for the study. However, when the aim of the study is metabolomic profiling rather than metabolomic fingerprinting, the technique conditions must be chosen and optimised to separate and detect the largest amount of compounds, with the broadest possible physical and chemical characteristics. GC-MS analysis is limited to the detection of the lower polar compounds. Therefore, it is likely that mid and high polarity 


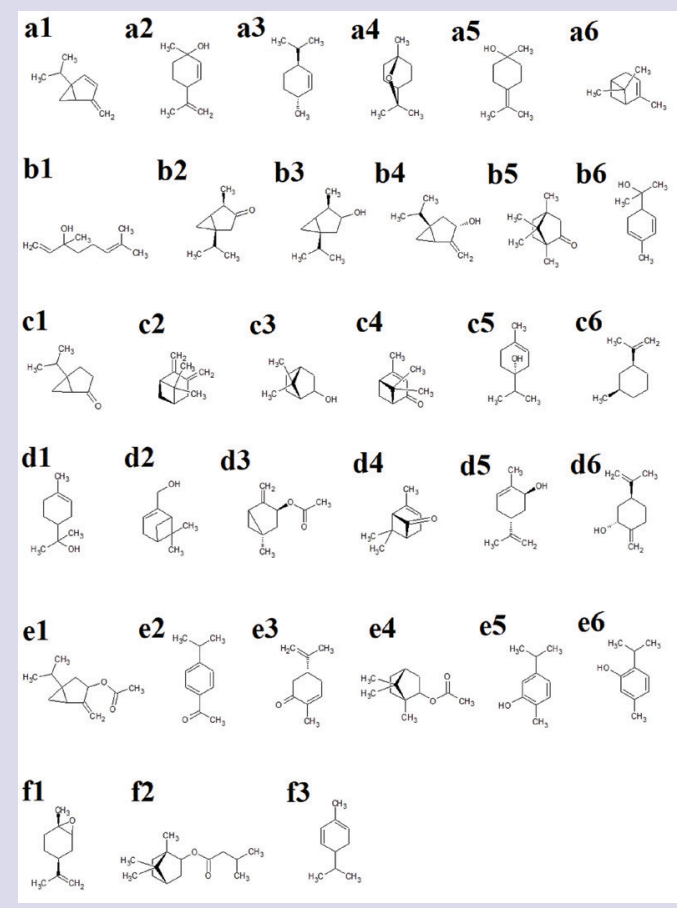

Figure 7: Monoterpenoid components detected in the aqueous and methanolic frankincense extracts: (a1) 2,4(10)-thujadiene, (a2) cis-p-mentha-2,8-dien-1-ol, (a3) myrtenylisovalerate, (a4) cineole, (a5) $\gamma$-terpineol, (a6) $\alpha$-pinene, (b1) 1,2-dimethyl1-cyclohexene, (b2) thujone, (b3) (1S,3S,4S,5R)-(+)-3-thujanol, (b4) (+)-sabinol, (b5) L-camphor, (b6) $\alpha$-phellandren-8-ol, (c1) sabina ketone, (c2) pinocarvone, (c3) endo-borneol, (c4) verbenone, (c5) terpinene-4-ol, (c6) cis-m-menth-8-ene, (d1) $\alpha$-terpineol, (d2) (-)-myrtenol, (d3) sabinyl acetate, (d4) 2-pinen-7-one, (d5) 3,4-dimethylbenzaldehyde, (d6) cis-p-mentha-1(7), 8-dien-2-ol, (e1) 4(10)-thujen-3-ol, acetate, (e2) p-cumic aldehyde, (e3) D-carvone, (e4) (-)-bornyl acetate, (e5) p-cymen-7-ol, (e6) thymol, (f1) limonene oxide, (f2) sabinylisobutanoate, (f3) $\alpha$-phellandrene.

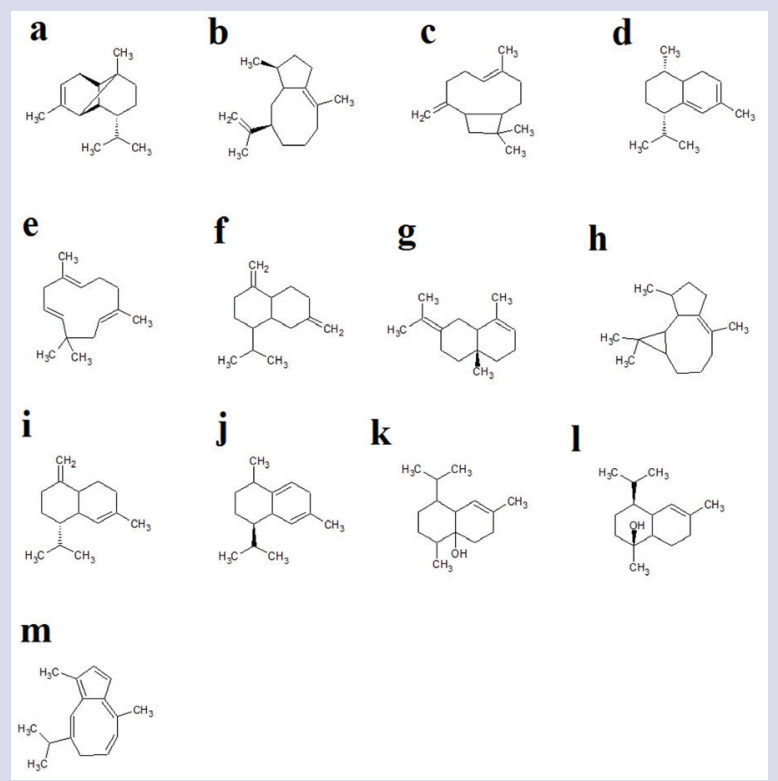

Figure 8: Sesquiterpenoid components detected in the aqueous and methanolic frankincense extracts: (a) copaene, (b) guaia-1(10), 11-diene, (c) caryophyllene, (d) cis-muurola-3,5-diene, (e) humulene, (f) epsilon-muurolene, (g) eudesma-4(14), 11diene, (h) (+)-ledene, (i) $\gamma$-muurolene, (j) cubenene, (k) epicubenol, (l) tau-cadinol, (m) azunol. 
compounds are present in these extracts and these compounds may also contribute to the growth inhibitory activity reported here. HPLC-MS is a good choice for the detection of compounds of mid-highly polar compounds. Thus, further studies are required, focussing on these techniques, to build a more complete understanding of the complete metabolomic profile of the frankincense extracts. Furthermore, it is noteworthy that mass spectral techniques are generally not capable on their own of differentiating between structural isomers. Further studies using a wider variety of techniques are required to confirm the identity of the compounds putatively identified here.

Whilst these studies have demonstrated the potential of the frankincense extracts to treat autoimmune disease, more work is required. This study has only tested these extracts against some microbial triggers of 3 autoimmune diseases (rheumatoid arthritis, ankylosing spondylitis and multiple sclerosis). The microbial triggers for several other autoimmune inflammatory disorders are also known. Borrelia burgdorferi is linked with Lyme disease. ${ }^{44}$ Similarly, members of the Enterobacteriaceae family are associated with Graves' disease and Kawasaki syndrome. Mycoplasma pneumoniae is associated with several demyelinating diseases. ${ }^{45}$ Whilst microbial triggers have also been postulated for lupus, the specific causative agents are yet to be identified. It would be interesting to extend our studies to also screen for the ability of the extracts to block these microbial triggers of autoimmune diseases.

\section{CONCLUSION}

The results of this study demonstrate the ability of frankincense extracts to block the growth of bacterial species associated with the onset of rheumatoid arthritis and ankylosing spondylitis and thus their therapeutic potential in genetically susceptible individuals. Further studies aimed at the purification and identification of bioactive components are needed to examine the mechanisms of action of these agents.

\section{ACKNOWLEDGEMENTS}

Financial support for this work was provided by the Environmental Futures Research Institute and the School of Natural Sciences, Griffith University.

\section{CONFLICT OF INTEREST}

The authors report no conflicts of interest.

\section{ABBREVIATION USED}

DMSO: Dimethyl sulfoxide; $\mathbf{L C}_{50}$ : The concentration required to achieve 50\% mortality; MIC: Minimum inhibitory concentration.

\section{REFERENCES}

1. Maloney GA. Gold, frankincense, and myrrh: an introduction to Eastern Christian spirituality. Crossroads Pub. Co; 1997: New York.

2. Frank MB, Yang $\mathrm{Q}$, Osban J, et al. Frankincense oil derived from Boswelliacarteri induces tumor cell specific cytotoxicity. BMC Complementary and Alternative Medicine. 2009;9(1):6. Doi:10.1186/1472-6882-9-6.

3. Thulin M, WarfaAM. The frankincense trees (Boswellia spp., Burseraceae) of northern Somalia and southern Arabia. Kew Bulletin. 1987;42:487-500.

4. Wootton S. (Ed.). Aromatherapy and Natural Health. GE Fabbri Ltd 2005; London, UK: 285-6.

5. Lemenith M, Teketay D. Frankincense and myrrh resources of Ethiopia: II. Medicinal and industrial uses. SINET: Ethiopian Journal of Science 2005;26(2):161-72.

6. Weckesser S, Engel K, Simon-Haarhaus B, et al. Screening of plant extracts for antimicrobial activity against bacteria and yeasts with dermatological relevance. Phytomedicine 2007;14(7):508-16.

7. Van Vuuren SF, Kamatou GPP, Viljoen AM. Volatile composition and antimicrobial activity of twenty commercial frankincense essential oil samples. South African Journal of Botany. 2010;76(4):686-91. Doi:10.1016/j.sajb.2010.06.001.

8. Ismail SM, Aluru S, Sambasivarao KRS et al. Antimicrobial activity of frankin- cense of Boswellia serrata. International Journal of Current Microbiology and Applied Science. 2014;3(10):1095-101.

9. Banno N, Akihisa T, Yasukawa K, et al. Anti-inflammatory activities of the triterpene acids from the resin of Boswellia carteri. Journal of Ethnopharmacology. 2006;107(2):249-53

10. Langmead L, Rampton DS. Review article: complementary and alternative therapies for inflammatory bowel disease. Alimentary Pharmacology and Therapeutics. 2006;23(3):341-9.

11. Chevrier MR, Ryan AE, Lee DY, et al. Boswelliacarterii extract inhibits TH1 cytokines and promotes TH2 cytokines in vitro. Clinical and Diagnostic Laboratory Immunology. 2005; 12(5):575-80

12. Sharma ML, Khajuria A, Kaul A, et al. Effect of salaiguggal ex-Boswelliaserrata on cellular and humoral immune responses and leucocyte migration. Agents Action. 1988;24(1-2):161-4

13. Ebringer A, Rashid T. Rheumatoid arthritis is an autoimmune disease triggered by Proteus urinary tract infection. Clinical and Developmental Immunology 2006;13(1):41-8.

14. Ebringer A, Cunningham $P, A$ mmadi $K$, et al. Sequence similarity between HLA-DR1 and DR4 subtypes associated with rheumatoid arthritis and Proteus/Serratia membrane haemolysins. Annals of the Rheumatic Diseases 1992;51(11):1245-6.

15. Cock I, van Vuuren SF. Anti-Proteus activity of some South African medicinal plants: their potential for the prevention of rheumatoid arthritis. Inflammopharmacology. 2014;22(1):23-6. Doi:10.1007/ s10787-013-0179-3.

16. Ebringer $A$, Rashid T, Wilson $C$ et al. Ankylosing spondylitis as an auto-immune disease linked to intestinal Klebsiella infection: prospects for a new therapeutic approach. Current Rheumatology Reviews. 2006;2(1):55-68.

17. Fielder M, Pirt SJ, Tarpey I et al. Molecular mimicry and ankylosing spondylitis: possible role of a novel sequence in pullulanase of Klebsiella pneumoniae. FEBS Letters. 1995;369(2):243-8.

18. Cock I, van Vuuren SF. The potential of selected South African medicinal with anti-Klebsiella activity for the treatment and prevention of ankylosing spondylitis Inflammopharmacology. 2015;23(1):21-35. DOI 10.1007/s10787-014-0222-z.

19. Hughes LE, Smith PA, Natt RS, et al. Cross-reactivity between related sequences found in Acinetobacter sp., Pseudomonas aeruginosa, myelin basic protein and myelin oligodendrocyte glycoprotein in multiple scherosis. Journal ofNeuroimmunology. 2003;144(1):105-15.

20. Ebringer A, Rashid T, Wilson C. The role of Acinetobacter in the pathogenesis of multiple sclerosis examined by using Popper sequences. Medical Hypotheses. 2012;78(6):763-9.

21. Sirdaarta J, Matthews B, White AR, et al. GC-MS and LC-MS analysis of Kakadu plum fruit extracts displaying inhibitory activity against microbial triggers of multiple sclerosis. Pharmacognosy Communications. 2015;5(2):100-15. DOI: 10.5530/pc.2015.2.2

22. Kalt FR, Cock IE. Gas chromatography-mass spectroscopy analysis of bioactive Petalostigma extracts: Toxicity, antibacterial and antiviral activities. Pharmacognosy Magazine. 2014;10(37):S37-49.

23. Sautron C, Cock IE. Antimicrobial activity and toxicity of Syzygium australe and Syzygium leuhmannii fruit extracts. Pharmacognosy Communications 2014;4(1):53-60.

24. Vesoul J, Cock IE. The potential of Bunya nut extracts as antibacterial functional foods. Pharmacognosy Communications 2012;2(1):72-9.

25. Hart C, Ilanko P, Sirdaarta J, et al. Tasmannia stipitata as a functional food/natural preservative: Antimicrobial activity and toxicity. Pharmacognosy Communications. 2014;4(4):33-47. DOI: 10.5530/pc.2014.4.4

26. Winnett $\mathrm{V}$, Boyer $\mathrm{H}$, Sirdaarta J, et al. The potential of Tasmannia lanceolata as a natural preservative and medicinal agent: Antimicrobial activity and toxicity. Pharmacognosy Communications. 2014;4(1):42-52.

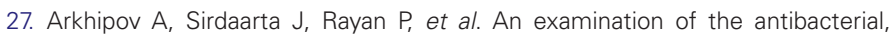
antifungal, anti-Giardial and anticancer properties of Kigelia africana fruit extracts. Pharmacognosy Communications. 2014;4(3):62-76.

28. Sautron C, Cock IE. Antimicrobial activity and toxicity of Syzygium australe and Syzygium leuhmanii fruit extracts. Pharmacog Commn. 2014;4(1):53-60.

29. Chikowe G, Mpala L, Cock IE. Antibacterial activity of selected Australian Syzygium species. PharmacogCommn. 2013;3(4):77-83.

30. Cock IE. Antimicrobial activity of Acacia aulacocarpa and Acacia complanta methanolic extracts. Pharmacognosy Communications. 2012;2(1):66-71.

31. Cock IE. Assessment of the toxicity of selected Australian native plant extracts using the Artemia franciscana nauplii bioassay. Internet Journal of Toxicology. 2008;5(2).

32. Ruebhart DR, Wikramasinghe WA, Cock IE. Protective efficacy of the antioxidants vitamin $\mathrm{E}$ and Trolox against Microcystis aeruginosa and microcystin-LR in Artemia franciscana nauplii. Journal of Toxicology and Environmental Health Part A. 2009;72(24):1567-75.

33. Cock IE, Ruebhart DR. Comparison of the brine shrimp nauplii bioassay and the ToxScreen-II test for the detection of toxicity associated with Aloe vera (Aloe barbadensis Miller) leaf extract. Pharmacognosy Research. 2009;1(2):98-101.

34. Alataha D, Kapral T, Smolen JS. Toxicity profiles of traditional disease modify- 
ing antirheumatic drugs for rheumatoid arthritis. Annals of the Rheumatic Diseases. 2003;62(5):482-6.

35. Cock IE. The phytochemistry and chemotherapeutic potential of Tasmannia lanceolata (Tasmanian pepper): A review. Pharmacognosy Communications. 2013;3(4):13-25

36. Bakkali F, Averbeck S, Averbeck D, et al. Biological effects of essential oils - A review. Food and CXhemical Toxicology. 2008;46(2):446-75

37. Salminen A, Lehtonen M, Suuronen T, et al. Terpenoids: Natural inhibitorsof NF- $\mathrm{kB}$ signalling with anti-inflammatory and anticancer potential. Celland Molecular Life Sciences. 2008;65(19):2979-99.

38. Lu XG, Zhan LB, Feng BA, et al. Inhibition of growth and metastasis of human gastric cancer implanted in nude mice by d-limonene. World Journal ofGastroenterology. 2004;10(14):2140-4.

39. Crowell PL. Prevention and therapy of cancer by dietary monoterpenes. Journal of Nutrition. 1999;129(3):775S-8S

40. Zhou JY, Tang FD, Mao GG, et al. Effect of a-pinene on nuclear translocation of
NF-kB in THP-1 cells. Acta Pharmacologica Sinica. 2004;25(4):480-4.

41. Claeson $P$, Rådström $P$, Sköld $O$, wt al. Bactericidal effect of the sesquiterpene T-cadinol on Staphylococcus aureus. Phytotherapy Research. 1992;6(2):94-8.

42. Huang M, Sanchez-Moreiras AM, Abel C, et al. The major volatile organic compound emitted from Arabidopsis thaliana flowers, the sesquiterpene (E)- $\beta$ caryophyllene, is a defense against a bacterial pathogen. New Phytologist. 2012;193(4):997-1008.

43. Cane DE, Ke N. Epicubenol synthase. Origin of the oxygen atom of a bacterial sesquiterpene alcohol. Bioorganic and Medicinal Chemistry Letters. 2000 10(2):105-7.

44. Beermann C, Wunderli-Allenspach H, Groscurth $P$, et al. Lipoproteins from Borreliaburgdorferi applied in liposomes and presented to dendritic cells induce CD8+ T-lymphocytes in vitro. Cell Immunol. 2000;201:124-31.

45. Kollef MH, West S, Davis DR, et al. Central and peripheral nervous system demyelination after infection with Mycoplasma pneumoniae. Evidence of an autoimmune process. Southern Med J. 1991;84,1255-8.

\section{PICTORIAL ABSTRACT}

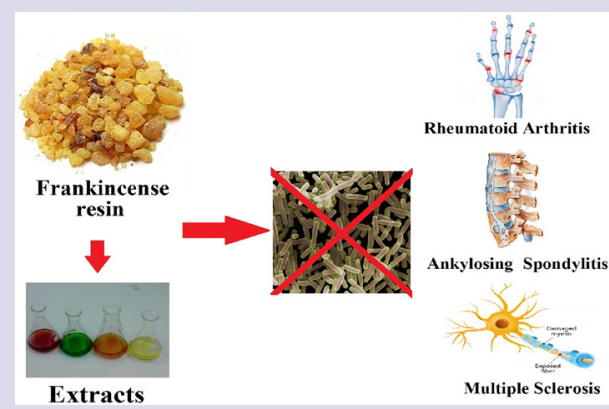

\section{SUMMARY}

- Rheumatoid arthritis may be triggered by P. mirabilis; ankylosing spondylitisby K. pneumoniae; and multiple sclerosis by $A$. baylyi and $P$. aeruginosa.

- Aqueous and methanolic frankincense solvent extracts inhibited these microbial triggers of autoimmune disease in vitro.

- The methanolic frankincense extract was a particularly potent inhibitor of P. mirabilis (MIC $60 \mu \mathrm{g} / \mathrm{mL}$ ).

- The aqueous extractswere alsoa potent inhibitor of $K$. pneumoniae (MIC $75 \mu \mathrm{g} / \mathrm{mL}$ ).

- The other extracts also inhibited bacterial growth, albeit with lower efficacy.

- Phytochemical profiling highlighted several terpenoids as potentially contributing to the growth inhibitory activity of the methanolic frankincense extract.

\section{ABOUT AUTHORS}

Dr lan Cock: Leads a research team in the Environmental Futures Research Institute and the School of Natural Sciences at Griffith University, Australia. His research involves bioactivity and phytochemical studies into a variety of plant species of both Australian and international origin including Aloe vera, South Asian and South American tropical fruits, as well as Australia plants including Scaevola spinescens, Pittosporum phylliraeoides, Terminalia ferdinandiana (Kakadu plum), Australian Acacias, Syzygiums, Petalostigmas and Xanthorrhoea johnsonii (grass trees). This range of projects has resulted in nearly 200 scientific publications in a variety of peer reviewed journals. 